\title{
Coryphodon, the northernmost Holarctic Paleogene pantodont (Mammalia), and its global wanderings
}

\author{
Mary R. Dawson
}

Received: 23 September 2011/Accepted: 27 October 2011/Published online: 15 November 2011

(C) Akademie der Naturwissenschaften Schweiz (SCNAT) 2011

\begin{abstract}
The pantodont Coryphodon is a frequently found component of early Eocene terrestrial faunas in North America, distributed widely from the Arctic to the Gulf Coast. The most northerly member of this genus of large herbivore is a new species that appears to be closest to the oldest known mid-latitude species, Coryphodon proterus from the Clarkforkian (Cf-2), late Paleocene, of Montana. Coryphodon is widely distributed during the early Eocene across the Holarctic, occurring also in England, Belgium, and France (MP7-9, early Eocene) on the one hand and Kazakhstan, Mongolia, and China (GashatanBumbanian, late Paleocene-early Eocene, Xinjiang, Shandong, and Shanxi) on the other. Although other genera of Coryphodontidae, as well as of other pantodont families, appear to have had more sedentary habits, Coryphodon is noted for its wide distribution. Adaptations to a warm temperate northern climate, including its northern light regime, may be postulated for this genus of pantodont as well as a pattern of dispersal leading to its wide range across the Holarctic.
\end{abstract}

Keywords Pantodont - Coryphodon - Eocene - Arctic . Holarctic distribution

\section{Introduction}

The order Pantodonta is of uncertain relationships within the Mammalia. Pantodonts were mostly large herbivorous or omnivorous quadrupeds that are known from many

M. R. Dawson $(\bowtie)$

Curator Emeritus, Vertebrate Paleontology, Carnegie Museum of Natural History, Pittsburgh, PA 15213, USA

e-mail: dawsonm@carnegiemnh.org
Paleogene terrestrial faunas across the Holarctic (Simons, 1960). Eight Paleogene pantodont families are recognized, each restricted to Asia or North America but not occurring on both continental areas except for one genus, Coryphodon, of the family Coryphodontidae (McKenna \& Bell, 1997), which is Holarctic in distribution. The other coryphodontid genera are only Asian, although no pantodonts are known from southern Asia or Africa. In North America, coryphodontids are known from Alabama and Mississippi on the Gulf Coast and southern Texas (Westgate, 2001; Beard \& Dawson, 2009) to the Eureka Sound Group on central Ellesmere Island, Nunavut, Canada, reported here.

\section{Systematic palaeontology}

Family Coryphodontidae (Marsh, 1876)

Genera of coryphodontids are: in North America, Coryphodon, late Paleocene (mid-Clarkforkian)-early middle Eocene (Bridgerian); in Europe, Coryphodon, early Eocene (Sparnacian); in Asia, Coryphodon, late Paleocene (Gashatan)-early Eocene (Bumbanian) Wutucoryphodon (including C. dabuensis), late Paleocene-early Eocene, Heterocoryphodon, early-middle Eocene, Asiocoryphodon, early-middle Eocene, Hypercoryphodon, middle Eocene, Metacoryphodon, middle Eocene, and Eudinoceras, middlelate Eocene.

Coryphodon (Owen, 1845)

Stratigraphic and geographic distribution: Late Paleocene (middle Clarkforkian)-early Eocene (Wasatchian), early middle Eocene (Gardnerbuttean) of North America; early Eocene (MP 7-9) of Europe; late Paleocene (Gashatan) early Eocene (Bumbanian) of Asia. 
Terminology for dental structures follows the basic plan outlined by Simpson (1929) with modifications related to $\mathrm{M}_{3}$ following Uhen and Gingerich (1995).

\section{Coryphodon pisuqti new species}

Coryphodon lobatus (Lucas, 1984, p. 39; 1998, p. 475). Coryphodon anthracoideus (Lucas, 1984, p. 37; 1998, p. 475).

Coryphodon subquadratus (Lucas, 1984, p. 39; 1998, p. 475).

Holotype: Canadian Museum of Nature (CMN) 32420, four associated large concretions: one containing right $\mathrm{P}_{1}$, alveoli of $\mathrm{P}_{2-4}$, and left $\mathrm{P}_{2}-\mathrm{M}_{2}$; one containing left $\mathrm{M}_{3}$; one containing left $\mathrm{P}^{2}-\mathrm{M}^{1}$; one containing right $\mathrm{M}^{2-3}$; and associated loose teeth and bones including an upper canine, and left $\mathrm{M}^{2-3}$ (locality 76-34).

Referred specimens CMN 30802, incomplete right mandible with $\mathrm{dP}_{3-4} ; \mathrm{CMN} 30803$, left $\mathrm{P}^{3}, \mathrm{CMN} 30811$, left $\mathrm{M}^{3} / 3$, canine, other tooth fragments; CMN 30961, partial skull; CMN 30965, right and left mandibles with teeth; CMN 30969, edentulous right mandible; CMN 30973, left mandible fragment, $\mathrm{M}_{3}$, skull fragments; CMN 30975, mandible fragment; CMN 32421, edentulous mandibles; CMN 32422, edentulous posterior part of mandible; CMN 32423, skull and mandible fragments, upper and lower teeth; CMN 32424, upper molar and other dental fragments; CMN 32431 , right and left partial mandibles; CMN NUFV24, incomplete maxilla. Other unnumbered tooth fragments and bones.

Horizon and localities Wasatchian; Margaret Formation (Miall, 1986; West \& Dawson, 1977, member IV), Eureka Sound Group (Ellesmere Island, Nunavut: Mattthew and Troelson peninsulas in Bay Fiord-Strathcona Fiord area; Stenkul Fiord).

Diagnosis Large species of Coryphodon $\left(\mathrm{M}_{3}\right.$ anteroposterior, $47.3 \mathrm{~mm}$ ). $\mathrm{M}_{3}$ long with distinct hypoconulid and supporting section of talonid root clearly set off by buccal and lingual grooves; $\mathrm{M}_{3}$ differs from that of $C$. proterus, in which the hypoconulid is even more pronounced, in having hypoconulid lobe relatively more linguad in position and thus closer to the cuspate entoconid; small metastylid on lingual wall anterior to entoconid. $\mathrm{I}^{1}$ largest upper incisor. $\mathrm{M}^{3}$ having long lingual side, distinct paraconule on protoloph situated at about transverse midpoint, postprotocrista extending obliquely posterobuccally from protocone, and complete anterior to lingual cingulum that posterolingually bears a distinct swelling ("hypocone"), as in C. proterus. Lower incisors wide transversely, flattened anteroposteriorly. Talonid of $\mathrm{P}_{4}$ relatively short anteroposteriorly.

Etymology Inuktitut, pisuqti (pee-shuk-tee), one who walks around most of the time, in reference to the Eocene wanderings of Coryphodon.
Description The following incorporates morphological details from the holotype, CMN 32420, and referred specimens from the Margaret Formation in the Bay FiordStrathcona Fiord area as well as from equivalent-aged deposits at Stenkul Fiord.

Skull No complete skull is known. CMN 30961 is a shattered partial skull including some of the skull roof. As in other Coryphodon the dorsal part of the skull is massive, having a width across the supraorbital crests estimated to be $18.3 \mathrm{~cm}$. The compact, heavy premaxillae, represented by several specimens, seem to have been relatively loosely attached to the maxilla. A small foramen occurs medially in line with $\mathrm{I}^{1}$ and a second, presumably the anterior palatine foramen, is higher, above the space between $\mathrm{I}^{1}$ and $\mathrm{I}^{2}$. The nasal incision slopes strongly posterodorsally, as is typical for the genus.

Mandible Only incomplete mandibles are represented (Fig. 1), exhibiting some size variation, as is usual in species of Coryphodon (Uhen \& Gingerich, 1995). On the lateral side of the jaw, two mental foramina occur in a line below the alveolus of the anterior premolar, the larger anterior foramen at about mid-depth of the ramus and slightly more ventral than the posterior foramen. Variably there may be another foramen in a line below $\mathrm{P}_{4}$. On the medial side of the ramus, the posterior edge of the symphysis is in a line between $\mathrm{P}_{2}$ and $\mathrm{P}_{3}$. CMN 32422 is the posterior part of a jaw with the alveolus for $\mathrm{M}_{3}$, part of the ascending ramus and the base of the condyloid process: the ascending ramus rises at about a right angle with the horizontal ramus, and the coronoid process is higher than the presumed position of the condyle, which is still well above occlusal level. On the essentially undivided medial surface of the ascending ramus there is a deep excavation within which is the opening ( $9 \mathrm{~mm}$ dorsoventrallly) of the inferior dental foramen. The lateral surface of the ascending ramus is concave with no separation of temporal and masseteric fossae.

Dentition There are no upper incisors in place in a premaxilla, so their relative size can be approximated only from an edentulous premaxilla. Based on alveolar size, the $\mathrm{I}^{1}$ root is larger than $\mathrm{I}^{2}$ and the $\mathrm{I}^{3}$ root is the smallest. The incisor crowns are slightly convex buccally, flattened lingually, and have a very narrow lingual cingulum. The upper canine in CMN 32420 is very large and roughly triangular in broken cross section. In CMN NUFV24, which retains broken canines of both sides preserved in the maxilla, $\mathrm{C}^{1}$ has a flattened medial side, and reaches its greatest width a little dorsal to mid-height on the buccal side. The latter is not as large as the tusk in the holotype but still has a massive root, extending far up into maxilla. Presumably both these specimens are males.

Of the upper premolars (Fig. 2), the crown of $\mathrm{P}^{1}$ is not preserved. In CMN NUFV24 part of the $\mathrm{P}^{1}$ root is present, 


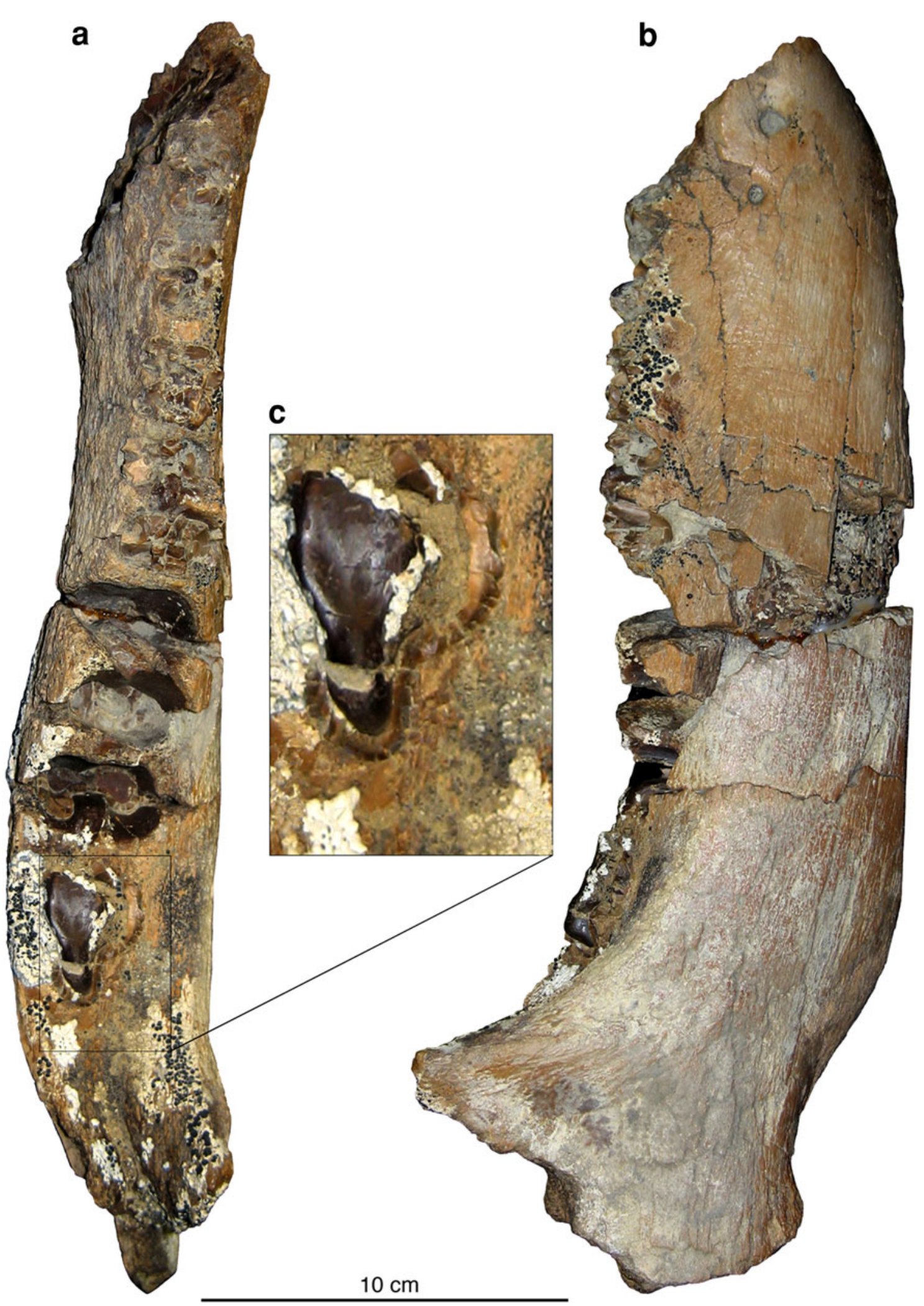

Fig. 1 Coryphodon pisuqti, CMN 30969, right mandible. a Dorsal view showing tooth roots, mandible reversed; $\mathbf{b}$ lateral view; $\mathbf{c}$ enlargement of root of $\mathrm{M}_{3}$ showing elongated hypoconulid lobe 


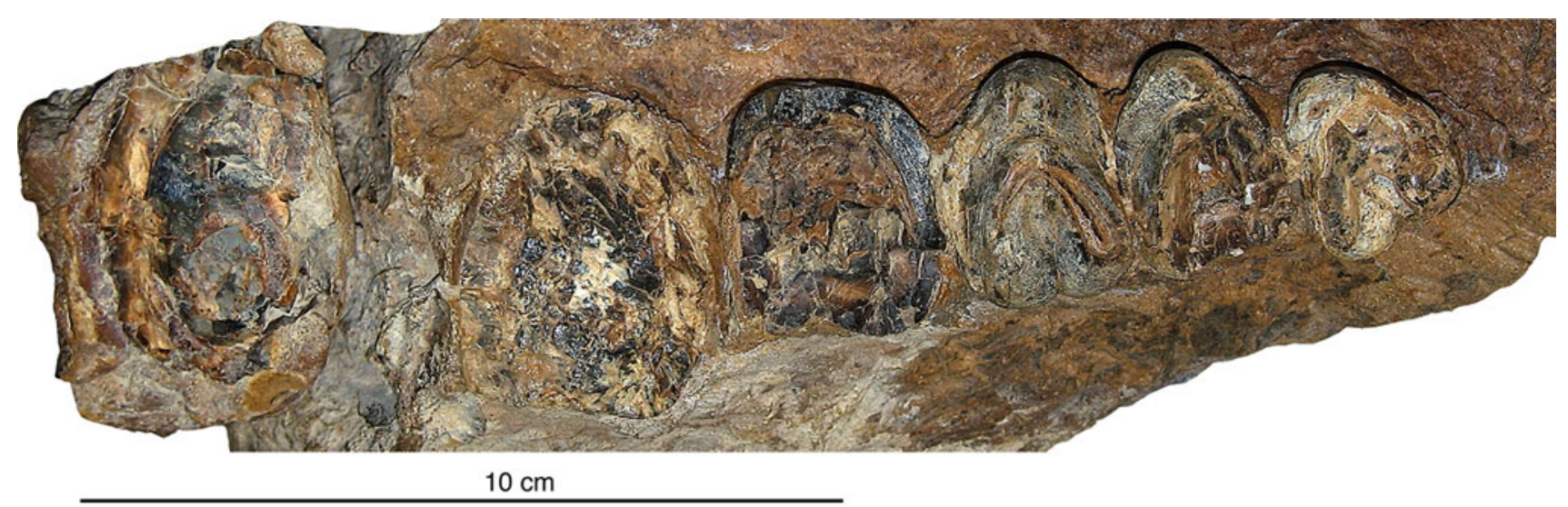

Fig. 2 Coryphodon pisuqti, CMN 32420, Holotype, left $\mathrm{P}^{2}-\mathrm{M}^{3}$, occlusal view

showing that the diastema between it and the canine alveolus is short $(12.6 \mathrm{~mm})$; on the other side a piece of maxilla suggests a single-rooted $\mathrm{P}^{1}$. The premolars increase in size from $\mathrm{P}^{2-4}$, all of which are three-rooted. $\mathrm{P}^{2}$ is transversely narrow at the parastyle, which extends less buccad than the metastyle; the protocone is separated by a groove from paracone-metacone. On the triangular, transversely elongated $\mathrm{P}^{2-4}$, there are anterior and posterior cingula but neither continues around the lingual side of the protocone.

The upper molars (Figs. 2, 3) increase in size from $\mathrm{M}^{1}$ to $\mathrm{M}^{3}$. Other than size, little can be determined of the morphology of any known M1, all specimens of which are either broken or too worn to show significant details of the occlusal surface. $\mathrm{M}^{2}$, a larger tooth than $\mathrm{M}^{1}$, has an anterior cingulum that continues around the lingual side to the "metaconule." The parastyle is large and elongated posteriorly. A swollen area ("paraconule") is situated at about the midpoint of the protoloph. The high, rounded paracone lacks a preparacrista and connects by a continuous ridge (postparacrista and premetacrista) to the metacone. This ridge, the metacone and the postmetacrista enclose a $\mathrm{V}$-shaped valley. There is no metastyle. The large $\mathrm{M}^{3}$ is wide lingually and has continuous anterior and lingual cingula. A rounded cuspule ("hypocone") is on the well developed posterolingual part of the cingulum. The parastyle is strong and has a ridge extending posteriorly from it. About at the midpoint of the long protoloph there is a small swelling ("paraconule"). Paracone and metacone are large cusps, connected by the postparacrista-premetacrista ridge, which is concave posterobuccally. There is no preparacrista. The large protocone is anterior to the buccolingual midline of the tooth and has a postprotocrista extending posterobuccally to form a ridge bounding the buccal side of the posterolingual cingular shelf.

The lower incisors are flattened and spatulate. None are preserved in place so it cannot be determined whether or not the $I_{1}>I_{2}>I_{3}$ size relationship of the upper incisors applied also to the lower teeth. The lower canine, variable in size, has wear facets that appear to be related to wear with $\mathrm{I}^{3}$ and the upper canine. Of the lower premolars, the only $\mathrm{P}_{1}$ represented is small and appears to be single rooted. Its trigonid is broken and possibly crushed, obscuring most of its morphology. There is a short diastema between it and $\mathrm{P}_{2}$. The talonid differs from those of $\mathrm{P}_{2-4}$ (Fig. 4) in having two narrow crests that converge at the posterior end of the tooth. $\mathrm{P}_{2-4}$, each two-rooted and having an anterior cingulid, increase in width toward the posterior. $\mathrm{P}_{2}$ has a shallower lingual valley than on $\mathrm{P}_{3-4}$. There is a more anterolingually protruding paraconid on $\mathrm{P}_{2-3}$ than on $\mathrm{P}_{4}$. The metaconid is a more prominent cusp on $\mathrm{P}_{4}$ than on the more anterior premolars, and the tooth is relatively short anteroposteriorly due to its more abbreviated talonid.

As with the upper molars, the lower molars (Figs. 4, 5) increase in size from $\mathrm{M}_{1-3}$. Each molar has anterior and posterior cingulids. Although the surface of $M_{1}$ is somewhat damaged in the holotype, essential details are preserved, showing the narrow cristid obliquid on $\mathrm{M}_{1}$ intersecting the metalophid approximately medially whereas on $\mathrm{M}_{2-3}$ the contact is more buccad. $\mathrm{M}_{3}$ is expanded posteriorly by the large hypoconulid, which is linguad of the midline. The single very large root that supports the entire talonid has well defined vertical grooves setting off the portion of the root below the hypoconulid. Anterior to the entoconid a small rounded metastylid occurs in the lingual edge of the talonid valley. The hypoconulid and entoconid are much better developed than in C. eocaenus. In the Clarkforkian C. proterus, the $\mathrm{M}_{3}$ hypoconulid is still more elongated posteriorly and is more medial in position than in C. pisuqti.

CMN 30802 (Fig. 6) is a partial right mandible of an immature $C$. pisuqti with $\mathrm{dP}_{3-4}$ in place. A round mental foramen occurs low, in a line below the talonid alveolus of $\mathrm{dP}_{2}$. The dorsal surface of the mandible anterior to $\mathrm{dP}_{3}$ is 
Fig. 3 Coryphodon pisuqti, CMN 32420, Holotype, right $\mathrm{M}^{2-3}$. a Occlusal view; b lingual view; c buccal view
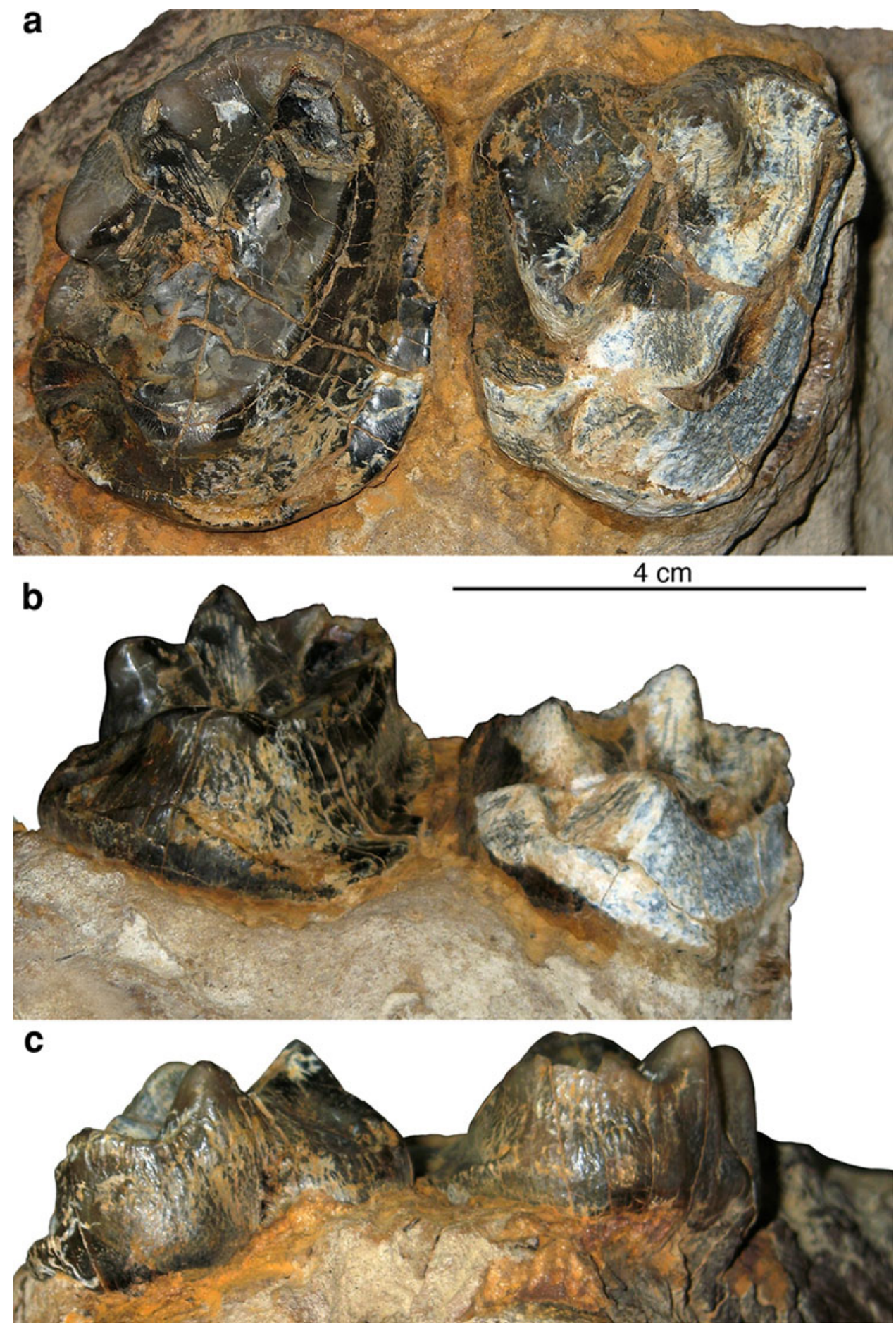

broken away, and the lateral side of the jaw shows an oval depression, possibly a bite mark, below the alveolus of $\mathrm{dP}_{2}$. The robust symphysis extends back to below the presumed alveolus for $\mathrm{dP}_{1}$. As preserved the anterior-most alveolus is a small, rounded, anterolateral facing recess, presumably for the lower deciduous canine. An elongate depression in the broken area may represent the alveolus for a single rooted $\mathrm{dP}_{1}$; posterior to this only the transversely elongated alveolus for the talonid root of $\mathrm{dP}_{2}$ is clearly preserved. Where unworn, the enamel of $\mathrm{dP}_{3-4}$ is distinctly wrinkled. $\mathrm{DP}_{3}$ is worn on the anterior surface of the paracristid and on the anteroposterior lingual lophid in the talonid. The trigonid of $\mathrm{dP}_{3}$ is high, with protoconid slightly higher than metaconid, and has anterior and lingual cingulids. The relatively small, low talonid, slightly broken posterobuccally, has a hint of a cuspate hypoconid. An anteroposterior 

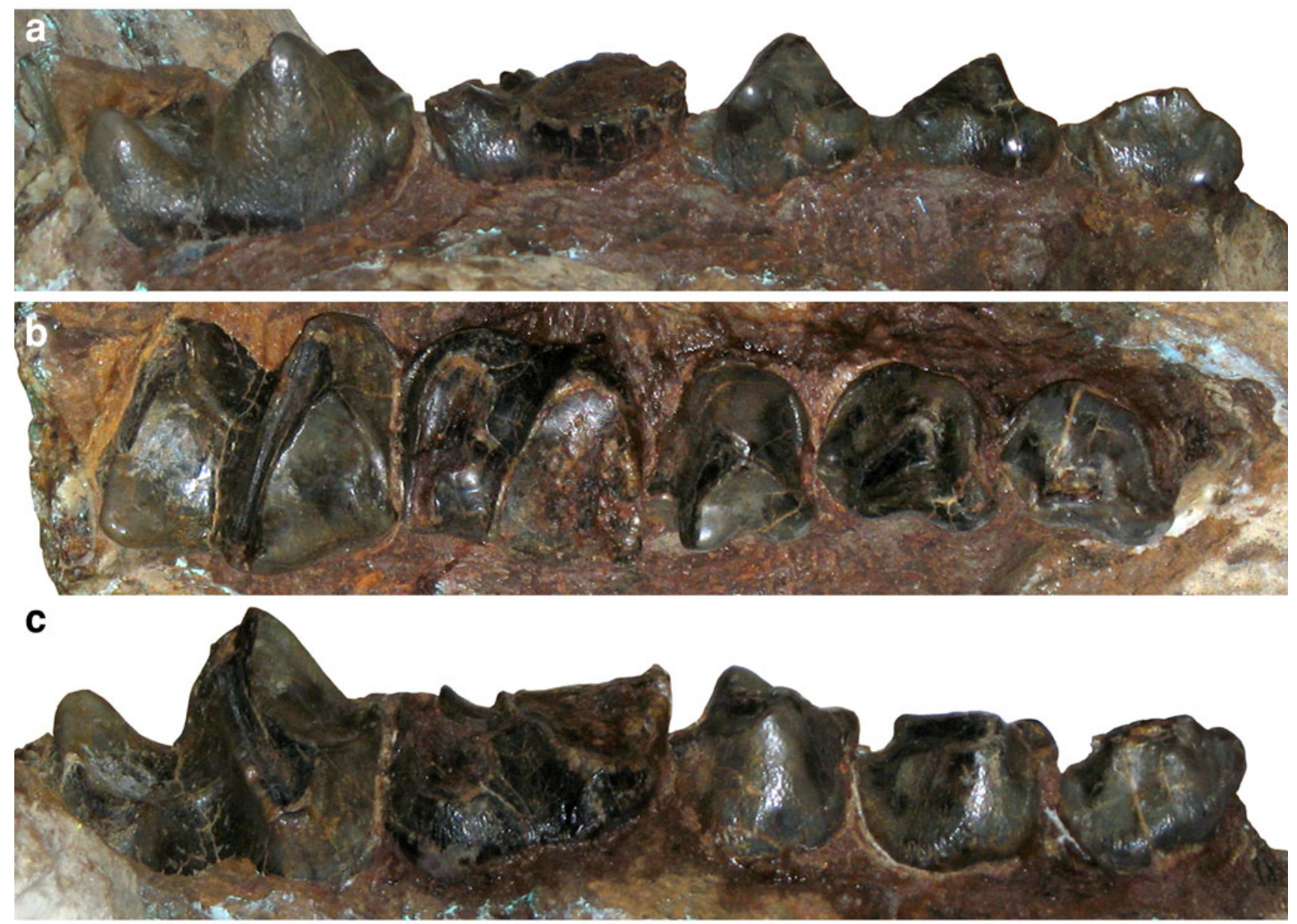

$10 \mathrm{~cm}$

Fig. 4 Coryphodon pisuqti, CMN 32420, Holotype, left mandible with $\mathrm{P}_{2}-\mathrm{M}_{2}$. a Lingual view; b occlusal view; c buccal view, jaw reversed

ridge, possibly representing a cristid obliquid, extends between the middle of the metacristid and the posterior edge of the tooth. Medial to this ridge there is only a faint suggestion of a posterolingual cuspid. Compared to Coryphodon sp. (Simons, 1960, Fig. 2) $\mathrm{dP}_{3}$ of C. pisuqti has a straighter metacristid, more open trigonid, and anteroposteriorly much shorter talonid. The completely unworn $\mathrm{dP}_{4}$ is molariform, having five well developed cusps. The tooth has anterior and posterior cingulids and a small lingual cingulid on the paraconid. The talonid is slightly wider than the trigonid. Compared to previously illustrated $\mathrm{dP}_{4}$ of Coryphodon sp. (Simons, 1960; Lucas \& Schoch, 1990), the metacristid is straighter and there is a short posterior spur on the posterior side of the metaconid. Posterior to $\mathrm{dP}_{4}$ the specimen preserves a large, empty crypt for $\mathrm{M}_{1}$.

Isolated postcranial bones are known for $C$. pisuqti but none are associated, nor are any complete enough for meaningful measurements.

Comparisons and relationships. So far as can be determined from the known specimens, Coryphodon pisuqti is the only pantodont taxon present in the Margaret Formation. All of the specimens having $\mathrm{M}_{3}$ exhibit the main characteristics of this taxon. Coryphodon pisuqti can serve as an index fossils within the Margaret Formation, being both widely distributed and morphologically distinctive, and exhibiting the ubiquity and presumed short geologic range that characterizes a useful index fossil (Simons, 1960). Postcranial bones lacking association with any dental remains are considered to represent the same taxon.

Coryphodon pisuqti is a large animal, only slightly smaller than the Clarkforkian Coryphodon proterus, the most primitive member of the genus known from well represented dental remains (Simons, 1960; Uhen \& Gingerich, 1995). It also resembles C. proterus in having a large hypoconulid on $\mathrm{M}_{3}$ that is distinctly set off from the remainder of the talonid, although relatively less elongated than in the Clarkforkian species. The hypolophid of $\mathrm{M}_{3}$ is weak and the hypoconulid is more linguad than in C. proterus. The cristid obliqua on $\mathrm{M}_{1-2}$ are stronger and longer in $C$. pisuqti and a metastylid is present only on $\mathrm{M}_{3}$, 

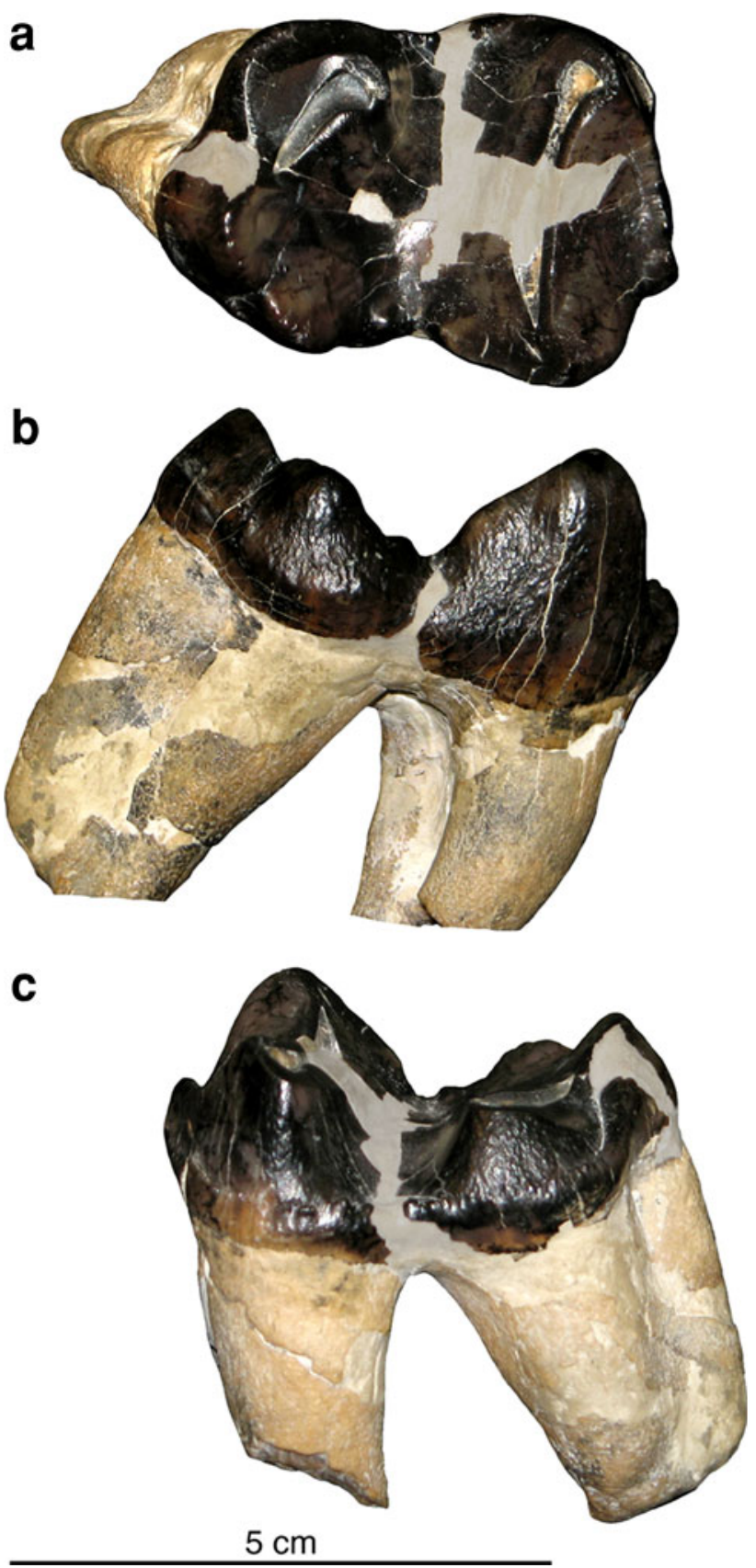

Fig. 5 Coryphodon pisuqti, CMN 30811, left $\mathrm{M}_{3}$. a Occlusal view; b lingual view; c buccal view

rather than on all three lower molars as in C. proterus. Several of the relatively primitive species of coryphodontid including C. eocaenus, Wutucoryphodon xianwui, and W. dabuensis have relatively long hypoconulids on $\mathrm{M}_{3}$ but less so than in $C$. proterus and $C$. pisuqti. This cusp has moved lingually and anteriorly in more derived species (Uhen \& Gingerich, 1995). The trends in coryphodontid dental evolution include reduction of the hypoconulid, as in the North American and European representatives (Hooker, 2010) of C. eocaenus, and increased bilophodonty of upper and lower molariform teeth, which occurs in more derived species.

Coryphodon was the dominant terrestrial herbivore of the Margaret Formation at a time of warm, humid temperate conditions with relatively mild summers and winters and a cold-month mean of about $5^{\circ} \mathrm{C}$ (Estes \& Hutchison, 1980). It must have been able to maintain significant population levels due both to a presumed scarcity of carnivores and an abundance of vegetation. In the warm temperate climate, even coupled with the dark Arctic winter, it could presumably browse on remaining vegetation, as do musk oxen even under Holocene severe winter conditions. Southward migration during the dark intervals across the large river valleys that later were flooded into fiords and sounds may also have been a possibility.

Remarks on the genus Coryphodon The northernmost record of Coryphodon is now from early Eocene (Wasatchian) deposits of the Margaret Formation, Eureka Sound Group, at localities about $78^{\circ}$ north latitude (Figs. 7, 8), in the Bay-Strathcona and Stenkul Fiord areas of Ellesmere Island, Nunavut, Canada (West \& Dawson, 1977; Miall, 1986), where it occurs as the largest and relatively well represented of the fossil mammals in these localities. Biostratigraphic evidence indicates a Wasatchian, probably mid-Wasatchian age for the Margaret Formation (Dawson, 2001). Coryphodon is one of the most widely represented mammals in the Margaret Formation. This record is based in large part on numerous fragments, but enough single teeth, dentitions and postcranial bones are present to show that a new species is represented. The most complete dental remains are enclosed in large siderite or limonite concretions, within which teeth may be well preserved, but the bone tends to merge into the surrounding matrix. Some specimens consist of well preserved bone, but all too frequently the teeth are broken away and only roots remain, probably as a result of Holocene permafrost action.

For the most part, dental characters distinguish species within Coryphodon (Simons, 1960; Uhen \& Gingerich, 1995), with some emphasis on the size and structure of $\mathrm{M}^{3} / 3$. Historically, species definitions within the genus have been rather unsettled, due in part to differing interpretations of individual variation. Thirty-five species of North American Coryphodon have been named since the first, Bathmodon radians Cope, 1872, but current work has restricted this to five species (Uhen \& Gingerich, 1995).

\section{Holarctic distribution of Coryphodon}

Coryphodon has long been recognized as having a wide geographic distribution, occurring in the early Eocene of both North America and Europe (Marsh, 1876; Owen, 1878). Recognition that the family occurred also in Asia came later 
Fig. 6 Coryphodon pisuqti, CMN 30802, partial right mandible with $\mathrm{dP}_{3-4}$. a Occlusal view; b lingual view; c buccal view

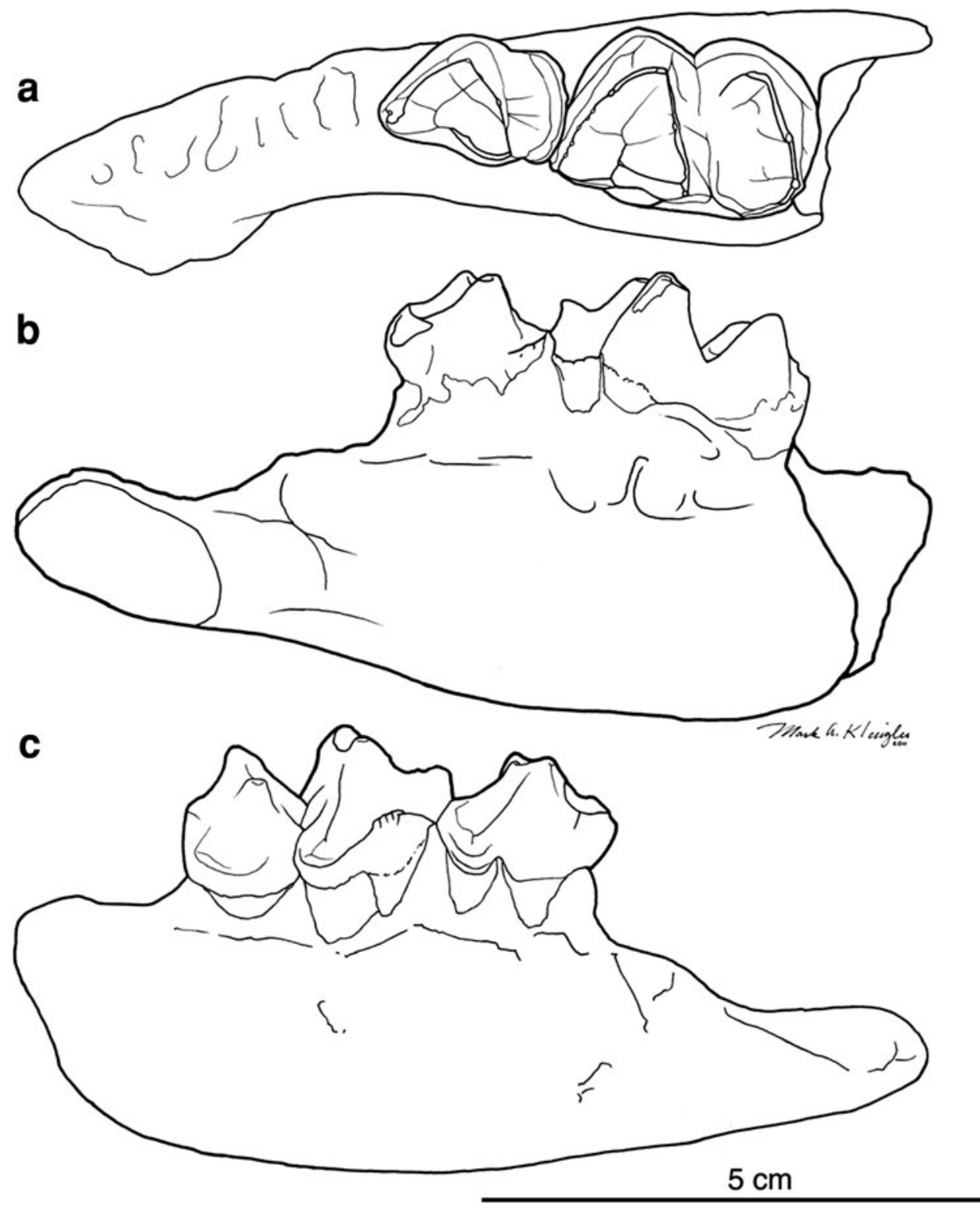

(Osborn \& Granger, 1931), when Eudinoceras was recognized to be a pantodont rather than a uintathere. The North American and European records are shorter and the coryphodontids less taxonomically diverse (late Paleocene to early middle Eocene, one genus, in the former, and early Eocene, one genus, in the latter) than the Asian, where the record spans the late Paleocene through the entire Eocene, during which time seven genera have been recognized (McKenna \& Bell, 1997; Tong \& Wang, 2006). Stratigraphic distribution supports the premise of an Asian origin for coryphodontids. Now, recognition of a relatively primitive species of Coryphodon in the high Arctic documents their movement across high latitudes in the Holarctic.

Definitive evidence on the phylogenetic position of C. pisuqti is absent. Perhaps the most parsimonious explanation is evolution of this species from the older and less derived $C$. proterus as its lineage followed cooler temperatures, typical of the later Paleocene, to higher latitudes during the time of the Paleocene-Eocene Thermal Maximum (PETM) at mid-latitudes. Persistence of $C$. pisuqti into the mid-Wasatchian at high latitudes might thus have been relictual. Another possibility is that it was an Arctic endemic. A more dynamic phylogenetic role could be postulated for $C$. pisuqti if it led to the origin of $C$. eocaenus, which is known from the earlier Eocene in midlatitudes of both North America and Europe, presuming that the species is indeed synonymous in both places.

Though relatively common, Coryphodon itself appears to be poorly understood. Clearly, as the only migrant in its family, its habits differed from those of other coryphodontids. Early Eocene climatic factors did not impede its distribution across the Holarctic. By the end of the early 


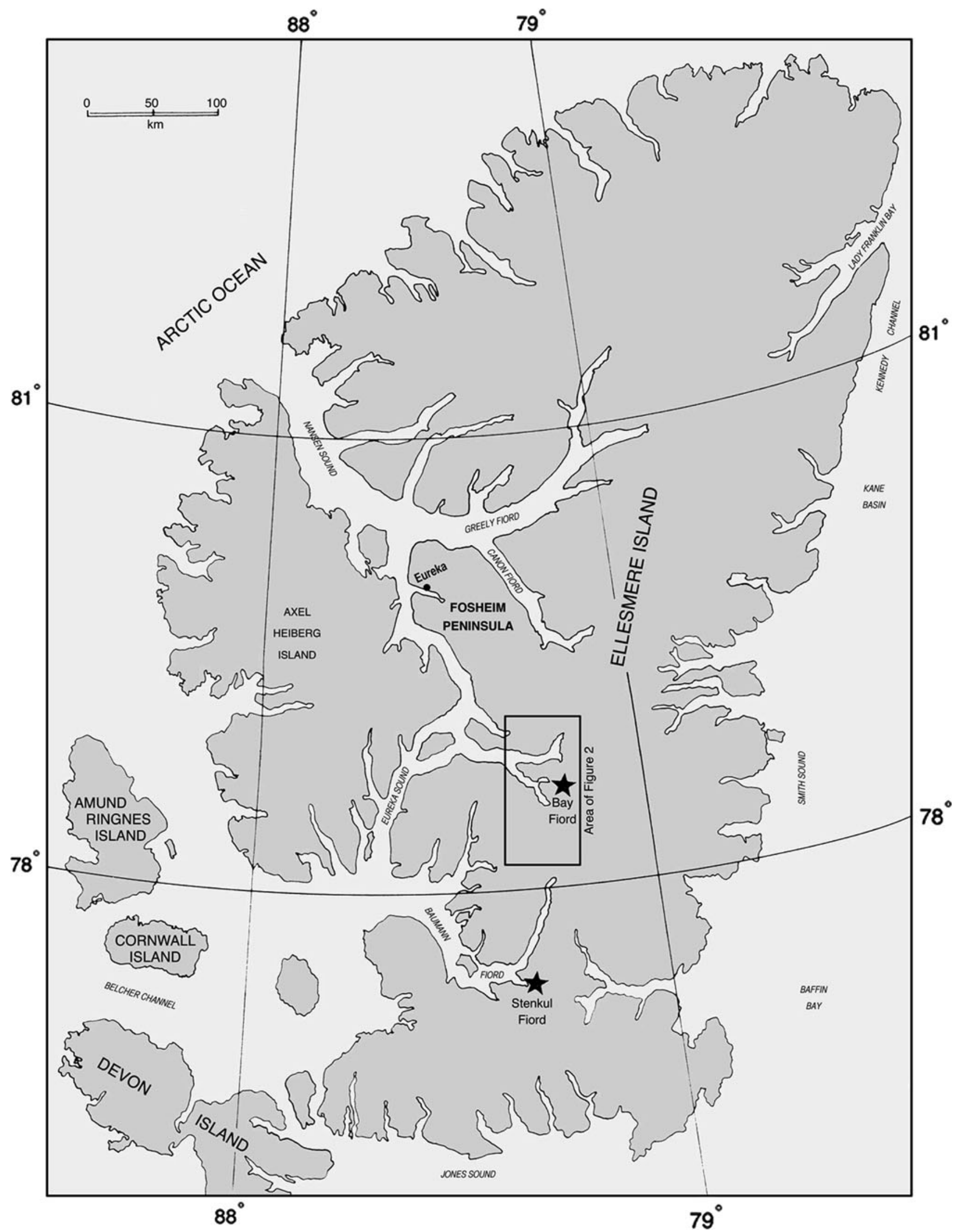

Fig. 7 Map of Ellesmere Island, Nunavut, Canada, showing main location near Bay Fiord of the Margaret Formation, Eureka Sound Group, and similarly aged deposits near Stenkul Fiord 
Fig. 8 Detailed map of the Bay Fiord-Srathcona Fiord area showing location of deposits of the Euraka Sound Group

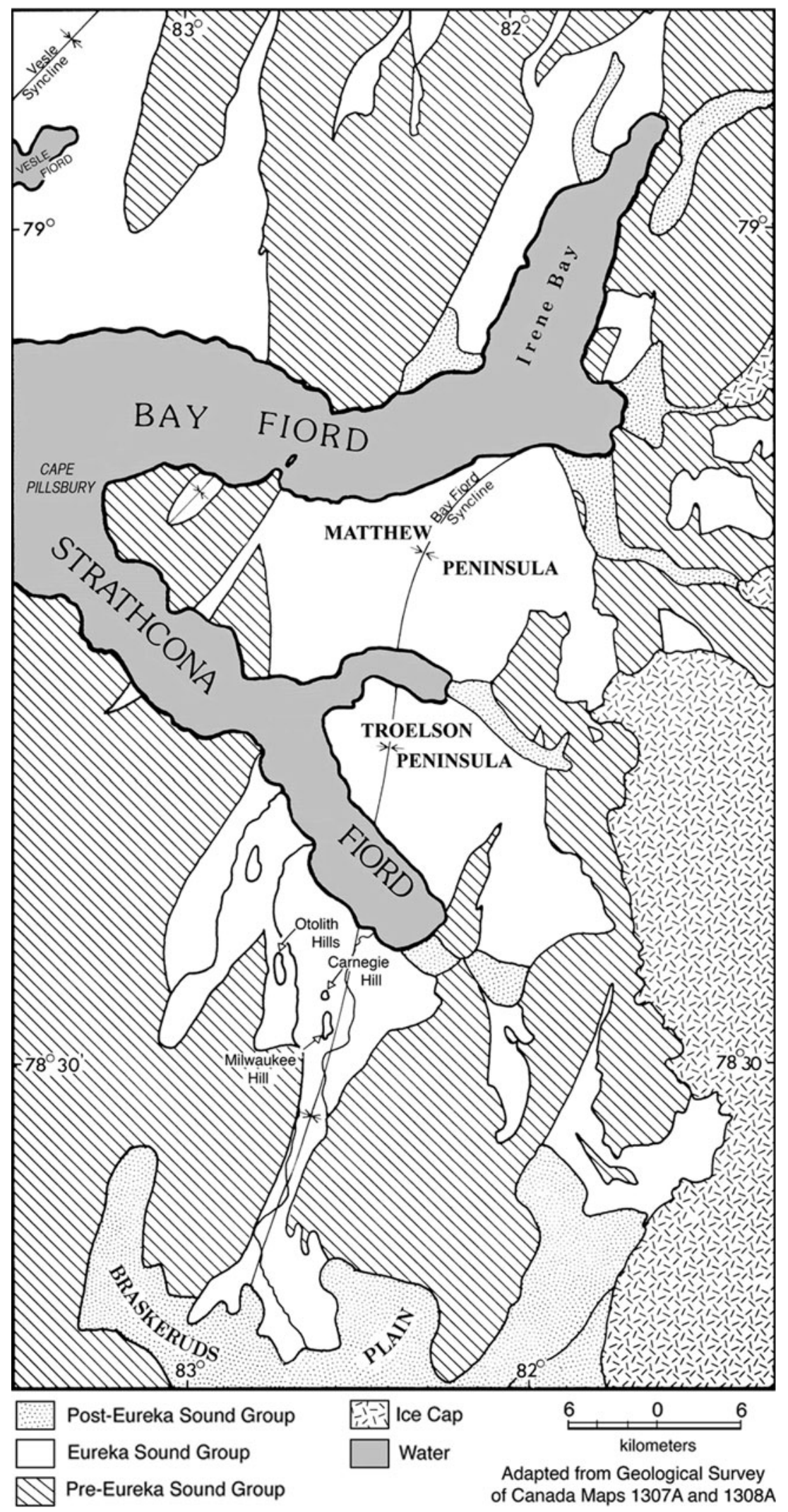


Eocene in Europe and the earliest middle Eocene in North America coryphodontids were gone. Their span in Asia was both much longer, until the end of the Eocene, and exhibited more taxonomic diversity, but without any more evidence of migrations between the current continents. Whether this was in response to cooling climates or to biotic factors remains to be discovered.

Acknowledgments First, most sincere congratulations are extended to Burkart Engesser, who for many years has been a valued paleontological colleague. With his unfailingly ironic sense of humor, Burkart will appreciate the fact that neither the pantodonts nor the Arctic Eocene investigated here are his major areas of interest or expertise! But, like Coryphodon, Burkart's career has included significant episodes of global wandering. Jarloo Kiguktak of Grise Fiord kindly and authoritatively provided guidance in the matter of the Inuktitut language. Gregg Gunnell (Museum of Paleontology, University of Michigan), Jeremy Hooker (British Museum of Natural History) provided access to specimens and most useful discussions of Holarctic Eocene events, and the paleontologists at the Muséum National de Histoire Naturelle, Paris, were most helpful in making specimens available for comparative study. Members of field crews who added to the collections of Coryphodon included J. J. Eberle, Leo Hickey, J.H. Hutchison, Kirk Johnson, M.C. and P. McKenna, Cliff Morrow, R.M. West. The support of Polar Continental Shelf Project, Canadian Department of Energy, Mines, and Resources, was essential for logistical and other help, always cheerfully provided. The Canadian Museum of Nature furnished curatorial assistance. Research grants from the National Geographic Committee for Research and Exploration made possible the field investigations on Ellesmere Island. Carnegie Museum's Mark Klingler assembled the illustrations for this study with his usual competence, and Xianghua Sun furnished valuable bibliographic assistance.

\section{Appendix 1}

Measurements of Coryphodon pisuqti, in $\mathrm{mm}$

\begin{tabular}{ll}
\hline Holotype CMN 32420 & \\
Upper canine & $40 \times 31.7$ \\
$\mathrm{P}^{2}$ anteroposterior & 20.0 \\
Transverse & 25.2 \\
$\mathrm{P}^{3}$ anteroposterior & 22.0 \\
Transverse (broken) & $\mathrm{ca} .30 .6$ \\
$\mathrm{P}^{4}$ anteroposterior & 22.8 \\
Transverse & 32.8 \\
$\mathrm{M}^{1}$ anteroposterior & 29.8 \\
Transverse & 34.7 \\
$\mathrm{M}^{2}$, left, anteroposterior & - \\
Transverse (on alveolus) & 43.8 \\
$\mathrm{M}^{2}$, right, anteroposterior & 39.4 \\
Transverse & 46.0 \\
$\mathrm{M}^{3}$, right, anteroposterior & 40.1 \\
Transverse & 50.9 \\
\hline
\end{tabular}

Appendix continued

\begin{tabular}{|c|c|}
\hline $\mathrm{P}_{1}$ anteroposterior & 15.2 \\
\hline Width & 10.4 \\
\hline $\mathrm{P}_{2}$ anteroposterior & 21.5 \\
\hline Width & 18.0 \\
\hline $\mathrm{P}_{3}$ anteroposterior & 22.4 \\
\hline Width & 20.2 \\
\hline $\mathrm{P}_{4}$ anteroposterior & 20.7 \\
\hline Width & 21.7 \\
\hline $\mathrm{M}_{1}$ anteroposterior & 30.5 \\
\hline Trigonid width & 26.0 \\
\hline Talonid width & 25.5 \\
\hline $\mathrm{M}_{2}$ anteroposterior & 37.0 \\
\hline Trigonid width & 31.1 \\
\hline Talonid width & 29.4 \\
\hline $\mathrm{M}_{3}$ anteroposterior & - \\
\hline Trigonid width & ca. 42.1 \\
\hline Talonid width & 32.2 \\
\hline \multicolumn{2}{|c|}{ CMN 30802, partial jaw, immature, with $\mathrm{dP}_{3-4}$} \\
\hline Depth jaw at $\mathrm{dP}_{4}$ & 26.4 \\
\hline $\mathrm{dP}_{3}$ anteroposterior & 18.2 \\
\hline Trigonid width & 13.4 \\
\hline Talonid width & 11.6 \\
\hline $\mathrm{dP}_{4}$ anteroposterior & 25.6 \\
\hline Trigonid width & 18.3 \\
\hline Talonid width & 17.7 \\
\hline \multicolumn{2}{|l|}{ CMN 30969 edentulous jaw } \\
\hline Depth right jaw at $\mathrm{M}_{3}$ trigonid & 53.2 \\
\hline Depth left jaw at $\mathrm{M}_{3}$ trigonid & 57.2 \\
\hline Depth left jaw at $\mathrm{M}_{2}$ talonid & 67.2 \\
\hline Width jaw at $\mathrm{M}_{2}$ talonid & 38.9 \\
\hline Width jaw at $\mathrm{M}_{3}$ talonid & 38.5 \\
\hline Alveolar length right $\mathrm{M}_{1-3}$ & 103.8 \\
\hline Alveolar length left $\mathrm{M}_{1-3}$ & 100.8 \\
\hline \multicolumn{2}{|l|}{ CMN 30975} \\
\hline Depth at talonid $\mathrm{M}_{2}$ & 66.4 \\
\hline Width at talonid $\mathrm{M}_{2}$ & 47.6 \\
\hline \multicolumn{2}{|c|}{$\begin{array}{l}\text { CMN } 32421 \text { edentulous jaws, not necessarily associated, both } \\
\text { posterior part }\end{array}$} \\
\hline Depth jaw at $\mathrm{M}_{3}$ talonid right & 57.9 \\
\hline Depth jaw at $\mathrm{M}_{3}$ talonid left & 58.9 \\
\hline Depth jaw at $\mathrm{M}_{2}$ talonid right & 59.9 \\
\hline Depth jaw at $\mathrm{M}_{2}$ talonid left & 57.8 \\
\hline \multicolumn{2}{|l|}{ CMN 32422} \\
\hline Depth jaw posterior to $\mathrm{M}_{3}$ hypoconulid & 68.6 \\
\hline Width jaw at talonid $\mathrm{M}_{3}$ & 44.1 \\
\hline \multicolumn{2}{|l|}{ CMN 30811 left $\mathrm{M}_{3}$} \\
\hline Anteroposterior & 46.6 \\
\hline Trigonid width & 31.6 \\
\hline Talonid width & 29.2 \\
\hline
\end{tabular}




\section{References}

Beard, K. C., \& Dawson, M. R. (2009). Early Wasatchian mammals of the Red Hot local fauna, uppermost Tuscahoma Formation, Lauderdale County, Mississippi. Annals of Carnegie Museum, 78(3), 193-243.

Cope, E. D. (1872). On the vertebrate fossils of the Wahsatch strata. Preliminary Report of the U.S. Geological Survey of Montana and Adjacent Territories; being a fifth Annual Report of Progress (vol. 3, pp. 350-355).

Dawson, M. R. (2001). Early Eocene rodents (Mammalia) from the Eureka Sound Group of Ellesmere Island, Canada. Canadian Journal of Earth Sciences, 38, 1107-1116.

Estes, R., \& Hutchison, J. H. (1980). Eocene lower vertebrates from Ellesmere Island, Canadian Arctic Archipelago. Palaeogeography, Palaeoclimatology, Palaeoecology, 30, 325-347.

Hooker, J. J. (2010). The mammalian fauna of the early Eocene Blackheath Formation of Abbey Wood, London. Monograph of the Palaeontographical Society, London (vol. 164, pp. 1-162).

Lucas, S. G. (1984). Synopsis of the species of Coryphodon (Mammalia, Pantodonta). New Mexico Journal of Sciences, 24(2), 33-42.

Lucas, S. G. (1998). Fossil mammals and the Paleocene/Eocene series boundary in Europe, North America, and Asia. In M.-P. Aubry, S. G. Lucas, \& W. A. Berggren (Eds.), Late Paleocene-early Eocene climatic and biotic events in the marine and terrestrial records (pp. 451-500). New York: Columbia University Press.

Lucas, S. G., \& Schoch, R. M. (1990). Ontogenetic studies of early Cenozoic Coryphodon (Mammalia, Pantodonta). Journal of Paleontology, 64(5), 831-841.

Marsh, O. C. (1876). On some characters of the genus Coryphodon Owen. American Journal of Science and Arts, 2, 425-428.

McKenna, M. C., \& Bell, S. K. (1997). Classification of mammals above the species level. New York: Columbia University Press.
Miall, A. D. (1986). The Eureka Sound Group (Upper CretaceousOligocene), Canadian Arctic islands. Bulletin of Canadian Petroleum Geology, 34(2), 240-270.

Osborn, H. F., \& Granger, W. (1931). Coryphodonts of Mongolia, Eudinoceras mongoliensis Osborn, E. kholobolchiensis sp. nov. American Museum Novitates, 459, 1-13.

Owen, R. (1845). Odontography; a treatise on the comparative anatomy of the teeth. London: Hippolyte Bailliere.

Owen, R. (1878). On the occurrence in North America of rare extinct vertebrates found fragmentarily in England. Annals and Magazine of Natural History, 5(2), 200-223.

Simons, E. L. (1960). The Paleocene Pantodonta. Transactions of the American Philosophical Society, 50, 1-99.

Simpson, G. G. (1929). A new Paleocene uintathere and molar evolution in the Amblypoda. American Museum Novitates, 387, $1-9$.

Tong, Y., \& Wang, J. (2006). Fossil mammals from the early Eocene Wutu Formation of Shandong Province. Palaeontologia Sinica (New series C, vol. 192, no. 28, pp. 1-195).

Uhen, M. D., Gingerich, P. D. (1995). Evolution of (Mammalia, Pantodonta) in the late Paleocene and early Eocene of northwestern Wyoming. Contributions from the Museum of Paleontology, University of Michigan (vol. 29, no. 10, pp. 259-289).

West, R. M., Dawson, M. R., Hutchison J. H. (1977). Fossils from the Paleogene Eureka Sound Formation, N.W.T., Canada: Occurrence, climatic and paleogeographic implications. In R. M. West (Ed.), Paleontology and plate tectonics (pp. 77-93). Milwaukee Public Museum Special Publication, 2.

Westgate, J. W. (2001). Paleoecology and biostratigraphy of marginal marine Gulf Coast Eocene vertebrate localities. In G. F. Gunnell (Ed.), Eocene biodiversity: Unusual occurrences and rarely sampled habitats (pp. 263-297). New York: Kluwer Academic/ Plenum. 